\title{
Evaluation on Minimum Landing Size Regulations in Turkish Marine Fisheries from Scientific Perspective ${ }^{\#}$
}

\author{
Ozan Soykan ${ }^{1, a, *}$ \\ *Corresponding author
}

${ }^{1}$ Faculty of Fisheries, Ege University, 35040 İmir, Turkey

\begin{tabular}{|c|c|}
\hline A R T I C L I N F O & A B S T R A C T \\
\hline $\begin{array}{l}\text { \#This study was presented as an oral } \\
\text { presentation at the 4th International } \\
\text { Anatolian Agriculture, Food, } \\
\text { Environment and Biology Congress } \\
\text { (Afyonkarahisar, TARGID 2019) } \\
\text { Research Article } \\
\text { Received : } 17 / 05 / 2019 \\
\text { Accepted : } 22 / 08 / 2019\end{array}$ & $\begin{array}{l}\text { Crucial point of fishery management is to let the fish or other species reproduce at least once during } \\
\text { their life. Therefore it is very important to determine the length at maturity (Lm) for given species } \\
\text { before the first capture. Focus of this study is to determine the consistency between scientific results } \\
\text { and minimum landing size (MLS) regulations in the marine fishery of Turkey. For this purpose, } 4 / 1 \\
\text { communique on commercial fishery }(2016 / 35) \text { published by the Republic of Turkey Ministry of } \\
\text { Agriculture and Forestry was investigated in order to expose the MLS of given species in Turkey. } \\
\text { Literature survey on Lm was also conducted preferably on studies which were performed in Turkish } \\
\text { waters or from the Mediterranean basin in order to avoid regional differences. While } 86 \text { marine } \\
\text { species were reported to be landed in the official fishery statistics, only } 49 \text { of them were appointed } \\
\text { with a MLS in the commercial fisheries regulation. It was determined that MLS of } 27 \text { species were } \\
\text { below the Lm according to the selected literature, } 7 \text { of them require result on } \mathrm{L}_{\mathrm{m}} \text {, status of the } 2 \\
\text { species couldn't be decided due to different length types and } 13 \text { (27\% of the decisions on MLS) of } \\
\text { them were found to be in accordance with the scientific literature on Lm. This study shows that MLS } \\
\text { regulation must be revised for most of the species in the surrounding waters of Turkey and } \\
\text { comprehensive maturity studies are urgently needed in order to fulfill the scientific gap. }\end{array}$ \\
\hline
\end{tabular}


The term "size" refers to total length in fishes, mantle length in cephalopods, carapace length in crustaceans and shell length in bivalves generally. Minimum landing weight is also applicable where it is difficult to measure the length like in octopus or where it is more practicable. Although there are studies reporting $\mathrm{L}_{\mathrm{m}}$ values of some commercial species in Turkey (Soykan et al., 2010; Metin et al., 2011; Soykan et al., 2015a; Soykan et al., 2015b), accordance between these values and the legislations were not deeply emphasized. As mentioned above, sustainable exploitation of fish stocks require scientific attitude especially on the maturity issue in order to make decision on MLS. The goal of the present study is to determine the consistency between minimum landing size limits of the given species in Turkey and the $\mathrm{L}_{\mathrm{m}}$ results of scientific studies. This paper is also considered to contribute the management of marine fisheries by updating the knowledge on $\mathrm{L}_{\mathrm{m}}$ for given species.

\section{Material and method}

Landed and marketed species in the Turkish fishery were derived from official fishery statistics of Turkey (TÜİK, 2018). 4/1 communique on commercial fishery (2016/35) published by the Republic of Turkey Ministry of Agriculture and Forestry was investigated in order to expose the MLS of given species in Turkey. Literature survey with regards to $\mathrm{L}_{\mathrm{m}}$ was also conducted preferably on studies which were performed in Turkish waters or from the Mediterranean basin in order to avoid regional differences. A detailed table including MLS, Lm values and their references with common and scientific names of the species was presented. Scientific names of the species were revised and appointed according to Froese and Pauly (2019), Mater et al., (2003) and WoRMS (2019).

\section{Results and Discussion}

86 marine species were reported to be landed in the Turkish official fishery statistics. On the other hand only 49 of them were appointed with a MLS in the commercial fisheries regulation. It was determined that MLS of 27 species were below the length at maturity according to the selected literature, 7 of them require result on $\mathrm{L}_{\mathrm{m}}$, status of the 2 species couldn't be decided due to different length types and 13 (27\% of the decisions on MLS) of them were found to be in accordance with the scientific literature on LFR.

Table 1 summarizes the consistency between scientific results on $\mathrm{L}_{\mathrm{m}}$ and minimum landing size (MLS) regulations in the marine fishery of Turkey. Merluccius merluccius and Solea solea which are highly valuable demersal fishes are not well managed. According to projection of this review, MLS of these species must be over 26 and $23 \mathrm{~cm} \mathrm{TL}$ respectively. Besides that, MLS of Trachurus mediterraneus which is one of the major pelagic fishes of Turkish waters should be increased to $20 \mathrm{~cm}$ TL. Another disconformity was observed in mullet species. While Mugil cephalus and Lisa aurata were in accordance with the given literature, MLS of 4 other mullets were below the $\mathrm{L}_{\mathrm{m}}$ and accurate finding are required for Mugil labeo. It is revealed that updated data are required for mullet species. Regarding the family scombridae, only MLS of Thunnus thynnus were found to be over the $\mathrm{L}_{\mathrm{m}}$. Euthynnus alletteratus, Scomber scombrus, Scomber japonicus and Sarda sarda were appointed with improper MLS according to literature. MLS of some other high commercials, Pomatomus saltatrix, Dentex dentex, Mullus surmuletus and Dicentrarchus labrax were also below the scientific limits. Ceyhan et al. (2007) reported the $\mathrm{L}_{\mathrm{m}}$ value of Pomatomus saltatrix to be $25.4 \mathrm{~cm}$ FL. Depending on their finding, $26 \mathrm{~cm}$ FL or $30 \mathrm{~cm}$ TL would be appropriate as MLS. One of the important negative situation belonged to Sardina pilchardus, the third important capture fish, with improper MLS appointment (Table 1).

$\mathrm{L}_{\mathrm{m}}$ value for Sardina pilchardus was given to be 12.1 cm TL by Akyol et al. (1996) in the Aegean Sea. Tsikliras and Koutrakis (2013) revealed the $\mathrm{L}_{\mathrm{m}}$ of Sarina pilchardus as $11.65 \mathrm{~cm}$ in the Greek coast of the Aegean Sea and recommended MLS to be $12 \mathrm{~cm}$ TL. Comparision of over mentioned studies showed that $12.5 \mathrm{~cm}$ TL MLS would be quite suitable for the species. Boops boops which is documented as an industrial species in the fishery statistics has no MLS. According to Soykan et al. (2015), Lm value was calculated to be $12.96 \mathrm{~cm}$ TL for females. Therefore a minimum $13 \mathrm{~cm}$ TL MLS is recommended for Boops boops in the Turkish waters. Although $\mathrm{L}_{\mathrm{m}}$ value for Sprattus sprattus was reported to be $9 \mathrm{~cm}$ TL in the Black Sea (De Silva, 1973), MLS for this species is missing in Turkish waters. So recommendation on MLS for sprat would be no less than $9 \mathrm{~cm}$ in Turkey. Status of the rest of the species were presented in Table 1.

During the investigation of the official fishery statistics, it was observed that the document exclude scientific names of the landed species which brings a difficulty in describing the species. Another deficiency of the mentioned document is the misuse of common names. One of the basic benefits of this study is considered to be the revision of scientific and common names of the species mentioned in the minimum landing size regulation of Turkey. MLS of missing 37 species (species which were not assigned a MLS) must urgently be appointed according to scientific results in order to make sustainable exploitation of the stocks. Comprehensive studies including stock estimation and monitoring should especially be focused on Engraulis encrasicholus, Sprattus sprattus, Sardina pilchardus, Merlangius merlangus euxinus, Trachurus trachurus, Sarda sarda, Trachurus mediterraneus, Boops boops, Mugil spp., Mullus surmuletus, Scomber japonicus and Pomatomus saltatrix which are the major species of the capture production. Among those, missing MLS values for Sprattus sprattus and Boops boops must be decided. Furthermore, $\mathrm{L}_{\mathrm{m}}$ values of Sardina pilchardus, Merlangius merlangus euxinus, Sarda sarda, Trachurus mediterraneus, Mullus surmuletus, Scomber japonicus and Pomatomus saltatrix must be updated in the light of scientific studies in Turkish waters and after that MLS's should be decided for sustainable exploitation of the stocks. Finally, this study shows that MLS regulation must be revised for most of the species in the surrounding waters of Turkey and comprehensive maturity studies are urgently needed in order to fulfil the scientific gap. 
Table 1 Comparison between the scientific results on $\mathrm{L}_{\mathrm{m}}$ and MLS regulation in Turkey.

\begin{tabular}{|c|c|c|c|c|c|}
\hline Common name (T/E) & Scientific name & $\begin{array}{l}\text { MLS / } \\
\text { MLW }\end{array}$ & $\mathrm{Lm}-\mathrm{LT}$ & Reference & A \\
\hline \multicolumn{6}{|c|}{ Fish } \\
\hline Akya/Leer fish & ichia amia & 40-TL & Required & & \\
\hline Bakalyaro/European hake & Ierluccius merluccius & 20-TL & $25.6 \mathrm{~cm}-\mathrm{TL}$ & Soykan et al., 2015a & - \\
\hline Barbunya/Red mullet & Iullus barbatus & 13-TL & $10.9 \mathrm{~cm}-\mathrm{TL}$ & Erdem, 2018 & + \\
\hline Çipura/Gilthead sea bream & parus aurata & 20-TL & $18.5 \mathrm{~cm}-\mathrm{TL}$ & Kınacigil et al., 2008 & + \\
\hline Dil/common sole & olea solea & 20-TL & $22.7 \mathrm{~cm}-\mathrm{TL}$ & Kınacigil et al., 2008 & - \\
\hline Eşkina/Brown meagre & iana umbra & $25-\mathrm{TL}$ & $22.0 \mathrm{~cm}-\mathrm{TL}$ & Engin and Seyhan 2009 & + \\
\hline Hamsi/Anchovy & ngraulis encrasicolus & 9-TL & $8 \mathrm{~cm}-\mathrm{TL}$ & Bingel et al., 1996 & + \\
\hline İstavrit/Atlantic horse mackerel & Trachurus trachurus & & $11.6 \mathrm{~cm}-\mathrm{TL}$ & Kınacigil et al., 2008 & + \\
\hline İstavrit/Mediterranean horse mackarel & Trachurus mediterraneus & $13-\mathrm{TL}$ & $19.1 \mathrm{~cm}-\mathrm{TL}$ & Karlou-Riga, 1995 & \\
\hline Kalkan/Turbot & Psetta maxima & 45-TL & $24.7 \mathrm{~cm}-\mathrm{TL}$ & Eryılmaz and Dalyan, 2015 & + \\
\hline Karagöz/Two banded sea bream & plodus vulgaris & 18-TL & $13.4 \mathrm{cr}$ & Soykan et al., & + \\
\hline Kefal/So-iuy mullet & Iugil so & 35-TL & 47.8 & Okumuş and Başçınar, 1997 & - \\
\hline Kefal/Boxlip & Mugil labeo & & Requi & & \\
\hline Kefal/Thicklip & Chelon labrosus & & $36.0 \mathrm{~cm}-\mathrm{TL}$ & Brusl & - \\
\hline nullet & Liza ramada & $20-\mathrm{TL}$ & $29.0 \mathrm{~cm}-\mathrm{TL}$ & Erge & - \\
\hline & Liza saliens & & $25.1 \mathrm{~cm}-\mathrm{TL}$ & 1994 & - \\
\hline mullet & Mugil cephalus & 30-TL & $29.1 \mathrm{~cm}-\mathrm{TL}$ & $\mathrm{McI}$ & + \\
\hline & isa aurata & 30-TL & $24.9 \mathrm{c}$ & & + \\
\hline Kılıç/s & iphias gladius & 125-LJFL & $149.0 \mathrm{~cm}-\mathrm{LJFL}$ & 2003 & - \\
\hline Kırlangıç/Tub gurnard & Chelidonichthys lucerna & 18-TL & $12.1 \mathrm{~cm}-\mathrm{TL}$ & 2008 & + \\
\hline Kırmızı mercan/c & Pagellus erythrinus & $15-\mathrm{TL}$ & $16.5 \mathrm{~cm}-\mathrm{TL}$ & Meti & - \\
\hline Koly & omber japonicus & 18-TL & $23.0 \mathrm{~cm}-\mathrm{TL}$ & et al., 2010 & - \\
\hline Levrel & icentrarchus labrax & $25-\mathrm{TL}$ & $30.1 \mathrm{~cm}-\mathrm{TL}$ & Kara & - \\
\hline jionfish & orpaena scrofa & $15-\mathrm{TL}$ & $21.0 \mathrm{~cm}-\mathrm{TL}$ & Kaim-Malka : & - \\
\hline Lüfer & matomus saltatrix & $18-\mathrm{TL}$ & $25.4 \mathrm{~cm}-\mathrm{FL}$ & Ceyhan et al & - \\
\hline Mezgit/Whiting & Merlangius merlangus & 13-TL & $14.5 \mathrm{~cm}-\mathrm{TL}$ & Genç et al., 1999 & - \\
\hline Minekop/Shi drum & Umbrina cirrhosa & 25-TL & Required & & \\
\hline Nil barbunyas1/Goldband goatfish & Upeneus moluccensis & $10-\mathrm{TL}$ & 11.0 & Özvarol et al., 2010 & \\
\hline Palamut/Bonito & Sarda sarda & $25-\mathrm{TL}$ & $37.0 \mathrm{~cm}-\mathrm{TL}$ & Cay & \\
\hline Pisi/Flounder & euronectes spp. & 20-TL & $22.5 \mathrm{~cm}-\mathrm{TL}$ & Koisor et al., 1 & - \\
\hline Sardalya/S & ardina pilchardus & $11-\mathrm{TL}$ & $12.1 \mathrm{~cm}-\mathrm{TL}$ & Akyol et al., 1996 & \\
\hline Tirs & Iinella aurita & $11-\mathrm{TL}$ & $16.8 \mathrm{c}$ & and Antonopc & \\
\hline Sargo & plodus sargus & 21-TL & $23.5 \mathrm{~cm}-\mathrm{TL}$ & et al., 2002 & \\
\hline Sarią̧ & yrosomus regius & $25-\mathrm{TL}$ & $57.2 \mathrm{~cm}-\mathrm{TL}$ & Gil e & \\
\hline Sarıkuyruk/ & ola dumerili & 30-TL & $113 \mathrm{~cm}$ & al., 1995 & \\
\hline & & $35-\mathrm{TL}$ & 52.0 & 1997 & \\
\hline Tel & us & 11-TL & $\Gamma \mathrm{L}$ & Kin & - \\
\hline *Bluefin tuna & ynnus & 115-TL/30 & FL & Cor & + \\
\hline & Scomber scombrus & 20-TL & 22.8 & Cike & - \\
\hline $\mathrm{Ya}$ & Euthynnus alletteratus & $45-\mathrm{TL}$ & 47.3 & Hajj & \\
\hline \multicolumn{6}{|c|}{ Moll } \\
\hline$\overline{\text { Aki }}$ & ditapes decussatus & 2.4-ShL & & & \\
\hline Beyaz kum & Chamelea gallina & 1.7-ShL & & & \\
\hline İstiridye/Edible oyster & Ostrea edulis & 6.0-ShL & Requ & & \\
\hline Kidonya/Warty venus & Venus verrucosa & 3.0-ShL & Required & & \\
\hline Kum şırlanı/Truncate d & Donax trunculus & 2.5-ShL & $1.8 \mathrm{~cm}-\mathrm{ShL}$ & 2002 & + \\
\hline & & $-/ 1 \mathrm{~kg}$ & & & \\
\hline \multicolumn{6}{|c|}{ Crust } \\
\hline & & & & & \\
\hline Istakoz/Eu & Homarus gammarus & $25-\mathrm{TL}$ & $11 \mathrm{~cm}-\mathrm{CL}$ & Lizarraga-Cubedo et al., 2003 & \\
\hline Mavi yengeç/Blue crab & Callinectes sapidus & 13-CL & $11.9 \mathrm{~cm}-\mathrm{CL}$ & Sümer et al., 2013 & \\
\hline
\end{tabular}

A: Accordance, MLS: Minimum landing size $(\mathrm{cm})$ - LT, MLW: Minimum landing weight (kg), $\mathrm{L}_{\mathrm{m}}$ : Lenght at maturity, LT: Length type, TL: Total length, FL: Fork length, SL: Standart length, LJFL: Lower jaw fork length, Shl: Shell length, CL: Carapace length. *One of the measures shall be considered, -: Inconvenient, +: Convinient, ?: Length type difference

\section{References}

Akyol O, Tokac A, Unsal S. 1996. An investigation on the growth and reproduction characteristics of the sardine (Sardina pilchardus Walbaum, 1792) in the bay of Izmir (Aegean Sea). Turkish Journal of Fisheries and Aquatic Sciences. 13:383-394.

Bingel F, Gücü AC, Nierman U, Kıdeyş AE, Mutlu E, Doğan M, Kayıkçı Y, Avşar D, Bekiroğlu Y, Genç Y, Okur H, Zengin M. 1996. Karadeniz stok tespiti projesi balıkçıllk araştırmaları. Final raporu. Deniz Bilimleri Enstitüsü, Erdemli ve Su Ürünleri Araştırma Enstitüsü, Yomra, TÜBITTAK. 172 p.
Brusle S, Brusle J. 1977. Les muges de Tunisie: Pe^che lagunaire et biologie de la reproduction de trois espe`ces (Mugil capito, $M$. cephalus et $M$. chelo) des lacs d'Ischkeul et de Tunis. Rapp Comm Int Mer Me'dit. 24:101-128.

Cayré P, Amon Kothias JB, Diouf T, Stretta JM. 1993. Biology of tuna. In (A. Fonteneau, J. Marcille). Resources, fishing and biology of the tropical tunas of the Eastern Central Atlantic. Rome, FAO. FAO Fisheries Technical Paper 292. pp:147244. ISBN 92-5-102652-1. 
Cetinić P, Soldo A, Dulčić J, Pallaoro A. 2002. Specific method of fishing for Sparidae species in the eastern Adriatic. Fisheries Research. 55:131-139.

Ceyhan T, Akyol O, Ayaz A, Juanes F. 2007. Age, growth, and reproductive season of bluefish (Pomatomus saltatrix) in the Marmara region, Turkey. ICES Journal of Marine Science. 64:531-536. DOI: 10.1093/icesjms/fsm026.

Cikeš Keč V, Zorica B. 2011. The reproductive traits of Scomber japonicus (Houttuyn, 1782) in the Eastern Adriatic Sea. Journal of Applied Ichthyology. 28:15-21. DOI: 10.1111/j.1439-0426.2011.01893.x.

Corriero A, Karakulak S, Santamarina N, Deflorio M, Spedicato D, Addis P, Desantis S, Cirillo F, Fenech-Farrugia A, Vasallo-Aguis R, De La Serna JM, Oray Y, Cau A, Megalofonou P, De Metrio G. 2005. Size and age at sexual maturity of female bluefin tuna (Thunnus thynnus L. 1758) from Mediterranean Sea. Journal of Applied Ichthyology. 21:483-486. DOI: 10.1111/j.1439-0426.2005.00700.x.

De Silva SS. 1973. Aspects of the reproductive biology of the sprat, Sprattus sprattus (L.) in inshore waters of the west coast of Scotland. Journal of fish biology. 5(6):689-705. DOI: 10.1111/j.1095-8649.1973.tb04505.x.

Engin S, Seyhan K. 2009. Age, growth, sexual maturity and food composition of Sciaena umbra in the south-eastern Black Sea, Turkey. Journal of Applied Ichthyology. 25:96-99. DOI: 10.1111/j.1439-0426.2008.01173.x.

Erdem Y. 2018. Karadeniz barbunya balığının (Mullus barbatus ponticus) ilk üreme boyunun tahmini. Journal of Advances in VetBio Science and Techniques. 3(2):30-37. DOI: 10.31797/vetbio.450369.

Ergene S. 1998. Reproduction characteristics of thinlip grey mullet Liza ramada (Risso, 1826) inhabiting AkgölParadeniz Lagoons (Göksü Delta). Turkish journal of Zoology. 24:159-164.

Eryilmaz L, Dalyan C. 2015. Age, Growth, And Reproductıve Biology Of Turbot, Scophthalmus Maximus (Actınopterygii: Pleuronectiformes: Scophthalmidae), From The SouthWestern Coasts Of Black Sea, Turkey. Acta Ichthyologica et Piscatoria. 45(2):181-188. DOI: 10.3906/zoo-1311-25.

Froese F, Pauly D. 2019. FishBase. [version 02/2019] Available from http://www.fishbase.org. Accessed 2019-03-18.

Genç Y, Zengin M, Basar S, Tabak İ, Ceylan B, Çiftçi Y, Üstündağ C, Akbulut B, Sahin T. 1998. Research Project for economic fishes. Tarım ve Köyişleri Bakanlığı Tarımsal Araştırmalar Genel Müdürlüğü, TAGEM/IY/96/17/3/001 Sonuç Raporu, Trabzon, Türkiye. Trabzon Su Ürünleri Merkez Araştırma Enstitüsü.

Gil MDM, Grau A, Basilone G, Ferreri R, Palmer M. 2013. Reproductive strategy and fecundity of meagre Argyrosomus regius Asso, 1801 (Pisces: Sciaenidae): implications for restocking programs. Scientia Marina. 77(1):105-118. DOI: 10.3989/scimar.03688.28A.

Goñi R, Quetglas A, Reñones O. 2003. Size at maturity, fecundity and reproductive potential of a protected population of the spiny lobster Palinurus elephas (Fabricius, 1787) from the western Mediterranean. Marine Biology. 143(3):583-592.

Hajjej G, Hattour A, Allaya H, Jarboui O, Bouain A. 2010. Biology of little tunny Euthynnus alletteratus in the Gulf of Gabes, Southern Tunisia (Central Mediterranean Sea). Revista de Biología Marina y Oceanografía. 45:399-406. DOI: $10.4067 /$ S0718-19572010000300004.

Hotos GN. 1999. Biology and population dynamics of Liza aurata (Risso, 1810) (Pisces: Mugilidae) of the MesolongiEtoliko lagoon. Doctorate thesis. University of Patra, Greece.

Jennings S, Kaiser MJ, Reynolds JD. 2001. Marine Fisheries Ecology. 1st Ed. Blackwell, Oxford. Blackwell Publishing. ISBN:0-632-05098-5.

Kaim-Malka RA, Jacob SS. 1985. Donne'es pre'liminaires sur la biologie de trois espe`ces de Scorpaenidae de la re'gion de Marseille. Rapp Comm Int Mer Médit, 29:45-47.
Kara MH. 1997. Cycle sexuel et fe'condite' du loup Dicentrarchus labrax (Poisson Moronide') du golfe d'Annaba. Cahiers de Biologie Marine. 38(3):161-168.

Karlou-Riga C. 1995. Biology and dynamics of the Trachurus species (Pisces, Carangidae) in the Saronikos Gulf. Doctorate thesis. Aristotle University of Thessaloniki, Greece.

Kınacıgil HT, İlkyaz AT, Metin G, Ulaş A, Soykan O, Akyol O, Gurbet R. 2008. Balıkçılık Yönetimi Açısından Ege Denizi Demersal Balık Stoklarının İlk Üreme Boyları, Yaşları ve Büyüme Parametrelerinin Tespiti. TÜBITAK, ÇAYDAG103 Y132 nolu Proje Kesin Raporu.

Kosior M, Kuczynski J, Grygiel W. 1996. Reproduction of Baltic flounder (Platichthys flesus L.) in relation to some somatic factors. ICES C.M. J:29.

Koutrakis ET. 1994. Biology and population dynamics of grey mullets (Pisces, Mugilidae) in the Lake Vistonis and the Lagoon of Porto-Lagos. Doctorate thesis. Aristotle University of Thessaloniki, Greece.

Lizarraga-Cubedo HA, Tuck I, Bailey N, Pierce GJ, Kinnear JAM. 2003. Comparisons of size at maturity and fecundity of two Scottish populations of the European lobster, Homarus gammarus. Fisheries Research. 65(1-3):137-152.

Marino G, Mandich A, Massari A, Andaloro F, Porrello S, Finoia MG, Cevasco F. 1995. Aspects of reproductive biology of the Mediterranean amberjack (Seriola dumerilii Risso) during the spawning period. Journal of Applied Ichthyology. 11(1-2):9-24.

Mater S, Kaya M, Bilecenoğlu M. 2011. Türkiye Deniz Balıkları Atlas1. Ege Üniversitesi Su Ürünleri Fakültesi Yayınları. ISBN: 9754835465. No:68. 169 p.

McDonough CJ, Roumillat WA, Wenner CA. 2005. Sexual differentiation and gonad development in striped mullet (Mugil cephalus L.) from South Carolina estuaries. Fishery Bulletin. 103(4):601-619.

Metin G, İlkyaz AT, Soykan O, Kınacıgil, HT. 2011. Biological characteristics of the common pandora, Pagellus erythrinus (Linnaeus, 1758), in the central Aegean Sea. Turkish Journal of Zoology. 35(3):307-315. DOI: 10.3906/zoo-0904-4.

Morales-Nin B, Moranta J. 1997. Life history and fishery of the common dentex (Dentex dentex) in Mallorca (Balearic Islands, western Mediterranean). Fisheries Research. 30(1-2): 67-76.

Okumus İ, Başçınar M. 1997. Population structure, growth and reproduction of introduced Pacific mullet, Mugil so-iuy, in the Black Sea. Fisheries Research. 33(1-3):131-137.

Orsi Relini L, Palandri G, Garibaldi F. 2003. Reproductive parameters of the Mediterranean swordfish. Biologia Marina Mediterranea. 10(2):210-222.

Silva L, Sobrino I, Ramos F. 2002. Reproductive biology of the common octopus, Octopus vulgaris Cuvier, 1797 (Cephalopoda: Octopodidae) in the Gulf of Cádiz (SW Spain). Bulletin of Marine Science. 71(2):837-850.

Soykan O, İlkyaz AT, Metin G, Kinacigil HT. 2010. Growth and reproduction of blotched picarel (Spicara maena Linnaeus, 1758) in the central Aegean Sea, Turkey. Turkish Journal of Zoology. 34:453-459. DOI: 10.3906/zoo-0903-29.

Soykan O, Ilkyaz AT, Metın G, Kinacig1l HT. 2015. Age, growth and reproduction of European hake (Merluccius merluccius (Linn., 1758)) in the Central Aegean Sea, Turkey. Journal of the Marine Biological Association of the United Kingdom. 95(4):829-837. DOI: 10.1017/S002531541400201X.

Soykan O, İlkyaz AT, Metin G, Kinacigil, HT. 2015. Growth and reproduction of Boops boops, Dentex macrophthalmus, Diplodus vulgaris, and Pagellus acarne (actınopterygii: perciformes: sparidae) from east-central aegean sea, Turkey. Acta Ichthyologica et Piscatoria. 45(1):39-55. DOI: 10.3750/AIP2015.45.1.05.

Sümer Ç, Teksam İ, Karatas H, Beyhan T, Aydin C.M. 2013. Growth and reproduction biology of the blue crab, Callinectes sapidus Rathbun, 1896, in the Beymelek Lagoon (southwestern coast of Turkey). Turkish Journal of Fisheries and Aquatic Sciences. 13:675-684. DOI: 10.4194/1303-2712-v13_4_13. 
Techetach M, Hernando-Casal JA, Saoud Y, Benajiba MH. 2010. Reproductive biology of chub mackerel Scomber japonicus in Larache area, Moroccan North Atlantic coast/Biologie de la reproduction du maquereau Scomber japonicus de la region de Larache, Atlantique Nord marocain. Cybium, International Journal of Ichthyology, 34(2):159-166.

Tsikliras AC, Antonopoulou E. 2006. Reproductive biology of the round sardinella (Sardinella aurita) in the northeastern Mediterranean Sea. Scientia Marina. 70(2):281-290. DOI: 10.3989/scimar.2006.70n2281.

Tsikliras AC, Koutrakis ET. 2013. Growth and reproduction of European sardine, Sardina pilchardus (Pisces: Clupeidae), in northeastern Mediterranean. Cahiers de Biologie Marine, 54(3):365-374.
TÜİK (Türkiye İstatistik Kurumu). 2018. Fishery Statistics 2018, Ankara.

WoRMS (2019). World Register of Marine Species. Available from http://www.marinespecies.org at VLIZ. Accessed 201903-18. doi:10.14284/170.

Zeichen MM, Agnesi S, Mariani A, Maccaroni A, Ardizzone GD. 2002. Biology and population dynamics of Donax trunculus L. (Bivalvia: Donacidae) in the South Adriatic coast (Italy). Estuarine, Coastal and Shelf Science. 54(6):971-982. DOI: 10.1006/ecss.2001.0868. 